\title{
U-Pb evidence for Late Neoarchean crustal reworking in the southern São Francisco Craton (Minas Gerais, Brazil)
}

\author{
JOSÉ C.S. CAMPOS ${ }^{1}$, MAURÍCIO A. CARNEIRO ${ }^{1}$ and MIGUEL A.S. BASEI ${ }^{2}$ \\ ${ }^{1}$ Departamento de Geologia da Escola de Minas da Universidade Federal de Ouro Preto \\ (DEGEO/EM/UFOP), Morro do Cruzeiro / Campus Universitário \\ 35400-000 Ouro Preto, MG, Brasil \\ ${ }^{2}$ Instituto de Geociências da Universidade de São Paulo, (IG/USP) Cidade Universitária, Butantã \\ 05508-900 São Paulo, SP, Brasil
}

Manuscript received on January 3, 2003; accepted for publication on July 7, 2003; contributed by Miguel A.S. BASEI*

\begin{abstract}
The Passa Tempo Metamorphic Complex is one of several metamorphic complexes that form the Archean sialic crust of the southern São Francisco Craton. It encompasses hypersthene-bearing gneissic rocks, with subordinate NW- or EW-trending mafic-ultramafic bodies and granodioritic to alkali-granitic, weakly foliated, and light-colored granitoids. These granitoids are the product of generalized migmatization that followed granulite-facies metamorphism. To determine the ages of the granulite-facies metamorphism and granitoid genesis, we obtained $\mathrm{U}-\mathrm{Pb}$ ages on zircon extracted from the mesosome and leucosome of the migmatitic gneisses. For the mesosome, a discordia that intercepts Concordia at $2622 \pm 18 \mathrm{Ma}$ is interpreted as a minimum age for granulite-facies metamorphism. For the leucosome, the upper intercept of discordia at $2599 \pm 45$ Ma corresponds to migmatization and granitoid genesis. Contemporaneous metamorphism and magmatism have been documented elsewhere in the São Francisco Craton, especially in the southern portion, demonstrating vast and vigorous reworking of sialic crust by the end of the Neoarchean.
\end{abstract}

Key words: craton, Archean, metamorphic complex, U-Pb geochronology, tectonic evolution, Brazil.

\section{INTRODUCTION}

The São Francisco Craton (Figure 1) is a Precambrian continental platform (Almeida 1977, 1981, Almeida et al. 1981, Alkmim et al. 1993) whose sialic crust consists predominantly of amphibolite facies TTG gneisses and minor granulite facies TTG gneisses that are accompanied by tonalitic-granitic plutons and ultramafic-mafic bodies of varied age and metamorphic grade. Some of these petrographic associations are named "metamorphic complexes",

\footnotetext{
* Member of Academia Brasileira de Ciências Correspondence to: Maurício Antônio Carneiro E-mail: mauricio@degeo.ufop.br
}

for example, the Bonfim Metamorphic Complex (around Bonfim village), Campo Belo Metamorphic Complex (around Campo Belo village), and Passa Tempo Metamorphic Complex (around Passa Tempo village).

Geochronologic studies place the geologic history of the Southern São Francisco Craton metamorphic complexes (Figure 1) in the Mesoarchean to Neoarchean time interval. Machado and Carneiro (1992) and Carneiro (1992) report single-crystal U$\mathrm{Pb}$ ages of zircon from the Bonfim Metamorphic Complex gneisses. The age values are of the order of $3280 \mathrm{Ma}, 2920 \mathrm{Ma}$ and $2772 \pm 6 \mathrm{Ma}$, interpreted 


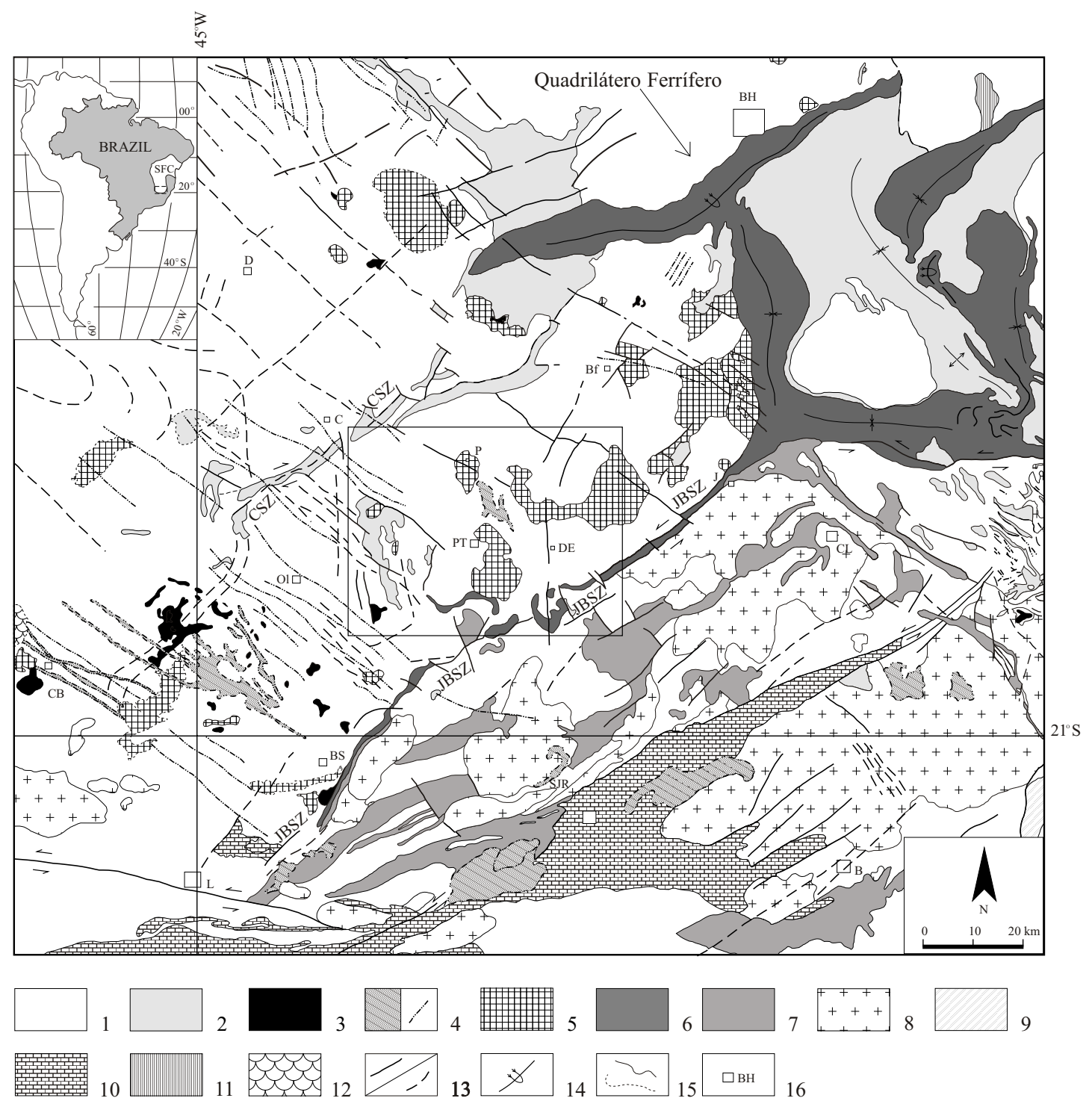

Fig. 1 - Geological map of the southern São Francisco Craton, pointing the Quadrilátero Ferrífero region and Passa Tempo Metamorphic Complex (assinalated rectangle) detailed in Figure 2. Key: 1 - Archean metamorphic complexes, partially reworked on Proterozoic time; 2 - Neoarchean Rio das Velhas Supergroup; 3 - Neoarchean ultramafic plutonic suite; 4 - Neoarchean and Mesoproterozoic gabbroic and dioritic rocks (sills and dikes); 5 - Neoarchean granitoids; 6 - Paleoproterozoic Minas Supergroup; 7 - Paleoproterozoic indiscriminate greenstone-type sequences; 8 - Paleoproterozoic granitoids; 9 - Mesoproterozoic (?) Dom Silvério Group; 10 Mesoproterozoic (?) São João Del Rei/Andrelândia Groups; 11 - Mesoproterozoic Espinhaço Supergroup; 12 - Neoproterozoic undivided cratonic cover; 13 - Faults and fractures (CSZ = Cláudio Shear Zone; JBSZ = Jeceaba-Bom Sucesso Shear Zone); 14 - Fold axes; 15 - Lithologic contacts; 16 - Cities: B = Barbacena, BH = Belo Horizonte, Bf = Bonfim, BS = Bom Sucesso, CB = Campo Belo, C = Cláudio, CL = Conselheiro Lafaiete, $\mathrm{DE}=$ Desterro de Entre Rios, D = Divinópolis, $\mathrm{J}=\mathrm{Jeceaba}, \mathrm{L}=\mathrm{Lavras}, \mathrm{Ol}=\mathrm{Oliveira}$, P = Piracema, PT = Passa Tempo, SJR = São João del Rei [geology modified after Dorr II (1969); Lima et al. (1974); Schorscher et al. (1982); Grossi Sad et al. (1983); Machado Filho et al. (1983); Silva (1985); Quéméneur (1987); Carneiro (1992); Raposo (1991); Brandalise (1991); Endo (1997); Oliveira and Carneiro (2001); Quéméneur and Noce (2000); Paciullo et al. (2000); Fernandes (2000); Jordt-Evangelista et al. (2000); Valeriano et al. (2000); Ávila (2000); Perillo (2000)]. 
as times of crystallization of the protolith, gneissification and reworking of the gneissic rocks. This reworking at $2772 \pm 6 \mathrm{Ma}$ occurred during the Rio das Velhas Tectonothermal Event (Carneiro 1992, Machado and Carneiro 1992, Machado et al. 1992, Carneiro et al. 1998). Southwest of Quadrilátero Ferrífero region (Figure 1), in the Campo Belo Metamorphic Complex context, distinct gneissic suites have been characterized based upon further mapping works, and isotopic and geochemical studies (Correia da Costa 1999, Fernandes 2000, Oliveira and Carneiro 2001). One of these gneissic suites, presents U-Pb (SHRIMP) zircon ages of $3205 \pm$ $17 \mathrm{Ma}, 3047 \pm 25 \mathrm{Ma}$ and $2839 \pm 17 \mathrm{Ma}$ (Teixeira et al. 1998). These ages are interpreted as times of crystallization of the protolith, and metamorphism and migmatization of the gneissic suite. Other zircon U-Pb data from Southern São Francisco sialic crust (Table I), indicate that granitoids were emplaced by the end of the Neoarchean, between 2612-2567 \pm 8 Ma (Noce 1995, Noce et al. 1998, Romano et al. 1991, Delhal and Demaiffe 1985).

All of these granitoids were emplaced during the Rio das Velhas III Event (RV3E, Endo 1997, Table I) that deformed the Rio das Velhas Supergroup, under a brittle-ductile, dextral transpressional regime with $\mathrm{N}$-S-trending flow plan and tectonic transport from NE to SW (Endo 1997). Despite Bonfim and Campo Belo metamorphic complexes, the isotopic database (Fiumari et al. 1985, Teixeira 1985) for Passa Tempo Metamorphic Complex is very meager. The existing data being limited to a $\mathrm{Rb}$-Sr isochron age of $2566 \pm 53 \mathrm{Ma}$, and $\mathrm{K}-\mathrm{Ar}$ apparent ages ranging from 2000 to $1750 \mathrm{Ma}$ (Figure 2, Table II). Now this paper reports the first U-Pb data on zircon from the Passa Tempo Metamorphic Complex.

\section{THE PASSA TEMPO METAMORPHIC COMPLEX}

\section{Geologic Setting}

The Passa Tempo Metamorphic Complex (Figure 2) is situated between Campo Belo Metamorphic Complex to the southwest, and the Bonfim meta- morphic Complex to the northeast. Although the Passa Tempo Metamorphic Complex oval geomorphologic feature is well characterized in topographic maps (at a 1:250,000 scale), its geologic boundaries with neighboring metamorphic complexes are not perfectly depicted (Figure 1). The Passa Tempo Metamorphic Complex encompasses tonalitic to granitic regional gneisses with minor mafic and ultramafic rocks, migmatites, and granitoids (Figure 2). Two prominent trends (NNE and NNW) characterize the gneissic layering. ENEtrending shear planes are superimposed (Figure 3).

In the Piracema and Serra dos Caetanos quarries (Figure 2), boudinage and small shear bands suggest normal to oblique sinistral dislocations parallel to sub-parallel to $\mathrm{N} 40^{\circ} \mathrm{E}, 30^{\circ} \mathrm{NW}$. Orthopyroxene-bearing gneissic rocks showing millimeter- to centimeter-size, even are meter-size, layering constitute the predominant lithotype. Modally, the rocks are tonalites, trondhjemites, granodiorites, quartz-monzonites, quartz-monzodiorites, and granites (Figure 4).

Felsic lithotypes, products of migmatization, occur widespread in the region as granitic bodies (l.s.), felsic mobilizates [according to Ashworth (1985)], diatexites resulting from advanced stages of partial melting (Ashworth 1985), and leucosomes [by Mehnert's (1968) definition]. These modal compositions vary from quartz-monzonitic/granodioritic to alkali-granitic (Figure 4). The mobilizates stretch out from meters to kilometers, and vary from leucosome portions of migmatized gneiss, to relatively large granitoid bodies.

Orthopyroxene is present everywhere in the gneisses, some of it occurring with clinopyroxene as a relict phase of the granulite-facies paragenesis. Replacement of pyroxene by hornblende and/or biotite is common (Figure 5, photomicrographs a, b). The felsic mobilizates exhibit magmatic features, such as inclusions of euhedral plagioclase in microcline crystals (Figure 5, c). Exsolution lamellae of orthopyroxene in clinopyroxene, and myrmekite at the contact between plagioclase and potassic feldspar (Figure 5,d), are features typical of retrograde metamorphism. 
TABLE I

Geochronologic summary of the most significant tectonic events that took place in the Southern São Francisco Craton and its southern-southeastern margin. References: 1 - Carneiro (1992); 2 - Endo (1997); 3 - Pinese et al. (1997); 4 - Noce et al. (1998); 5 - Romano et al. (1991); 6 - Delhal and Demaiffe (1985); 7 - Quéméneur and Vidal (1989); 8- Teixeira et al. (1987); 9 - Teixeira and Martins (1996); 10 Ávila (2000); 11 - Noce et al. (1997); 12 - Jordt-Evangelista et al. (2000); 13 - Teixeira (1985); 14 - Dussin et al. (1993); 15 - Söllner and Trouw (1997); 16 - Machado et al. (1996); 17 - This paper. Abbreviations: $\mathrm{Zr}=$ zircon; Det. $\mathrm{Zr}$. = detrital zircon; $(\mathbf{n})=$ reference.

\begin{tabular}{|c|c|c|c|}
\hline Event & Time interval & \multicolumn{2}{|c|}{ Deformation/metamorphism } \\
\hline Rio das Velhas $^{(1)}$ & $2780-2700 \mathrm{Ma}$ & \multicolumn{2}{|l|}{ 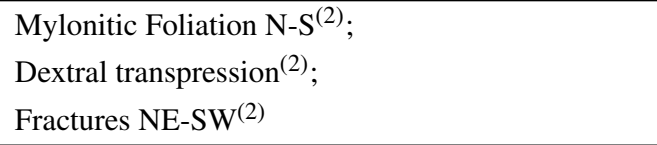 } \\
\hline Rio das Velhas II ${ }^{(2)}$ & $2658-2612 \mathrm{Ma}$ & \multicolumn{2}{|l|}{$\begin{array}{l}\text { Mylonitic Foliation } \mathrm{N}-\mathrm{S}^{(2)} \\
\text { Sinistral transpression } \\
\text { Fractures } \\
\text { NW-SE } \\
\text { (2) }\end{array}$} \\
\hline Rio das Velhas III ${ }^{(2)}$ & $2612-2555 \mathrm{Ma}$ & \multicolumn{2}{|c|}{$\begin{array}{l}\text { Deformation of Maquiné Group }{ }^{(2)} \text {; } \\
\text { Dextral transpression }^{(2)}\end{array}$} \\
\hline Transamazônico I ${ }^{(2)}$ & $2250-2059 \mathrm{Ma}$ & \multicolumn{2}{|c|}{$\begin{array}{l}\text { Deformation of Minas Supergroup } \\
\text { Dextral transpression / transtraction } \\
\text { Amphibolite facies metamorphism } \\
\text { A2); } \\
\text { Uplift at W and NW of the } \mathrm{QF}^{(2)}\end{array}$} \\
\hline Transamazônico II ${ }^{(2)}$ & $2059-1900 \mathrm{Ma}$ & \multicolumn{2}{|c|}{$\begin{array}{l}\text { Deformation of Itacolomi Group } \\
\text { Sinistral transpression/transtraction }^{(2)} \\
\text { Discontinuities reactivation }^{(2)} \\
\text { Normal faults }^{(2)}\end{array}$} \\
\hline$?$ & $?$ & \multicolumn{2}{|c|}{$\begin{array}{l}\text { Pre-Andrelândia and } \\
\text { São João Del Rei groups sedimentation }\end{array}$} \\
\hline$?$ & $?$ & \multicolumn{2}{|c|}{ Pre-Espinhaço Supergroup sedimentation } \\
\hline Brasiliano & & \multicolumn{2}{|c|}{$\begin{array}{l}\text { Blue schist facies metamorphism }{ }^{(15)} \\
\text { Amphibolite to granulite facies metamorphism }^{(15)}\end{array}$} \\
\hline Event & \multicolumn{2}{|l|}{ Igneous activity/age/method } & $\begin{array}{l}\text { Stratigraphic unit/ } \\
\text { ages/method }\end{array}$ \\
\hline \multirow[t]{3}{*}{ Rio das Velhas ${ }^{(1)}$} & \multicolumn{2}{|c|}{ Samambaia Tonalite $^{(1)} / 2780+3 /-2 \mathrm{Ma} / \mathrm{U}-\mathrm{Pb}(\mathrm{Zr})$} & \multirow{3}{*}{$\begin{array}{l}\text { Nova Lima Group } \\
\text { /3539 - 2996Ma }{ }^{(16)} \\
\text { /Pb-Pb/Det. } \mathrm{Zr}\end{array}$} \\
\hline & Mamona Garnodiorite ${ }^{(1)} / 272$ & $\mathrm{U}-\mathrm{Pb}(\mathrm{Zr})$ & \\
\hline & Brumadinho Granite $^{(1)} / 2703$ & $\mathrm{Ia} / \mathrm{U}-\mathrm{Pb}(\mathrm{Zr})$ & \\
\hline \multirow[t]{2}{*}{ Rio das Velhas II ${ }^{(2)}$} & \multicolumn{2}{|c|}{ Desterro Gneiss protolith $^{(17)} / 2622 \pm 18 \mathrm{Ma} / \mathrm{U}-\mathrm{Pb}(\mathrm{Zr})$} & \\
\hline & \multicolumn{2}{|c|}{ Gabbronoritic dikes NW-SE ${ }^{(3)} / 2658 \pm 44 \mathrm{Ma} / \mathrm{Sm}-\mathrm{Nd}$ (isochron) } & \\
\hline \multirow[t]{5}{*}{ Rio das Velhas III ${ }^{(2)}$} & \multicolumn{2}{|c|}{ Salto Paraopeba Granite ${ }^{(4)} / 2612 \pm 3 \mathrm{Ma} / \mathrm{U}-\mathrm{Pb}(\mathrm{Zr})$} & \multirow{5}{*}{$\begin{array}{l}\text { Maquiné Group } \\
\text { (Casa Forte Formation) } \\
\text { /3261 - } 2877 \mathrm{Ma}^{(16)} \\
/ \mathrm{Pb}-\mathrm{Pb} / \mathrm{Det} . \mathrm{Zr}\end{array}$} \\
\hline & \multicolumn{2}{|c|}{ Caio Martins Granite ${ }^{(5)} / 2593 \pm 18 \mathrm{Ma} / \mathrm{U}-\mathrm{Pb}(\mathrm{Zr})$} & \\
\hline & \multicolumn{2}{|c|}{ Bação Granitoids $^{(6)} / 2567 \pm 8 \mathrm{Ma} / \mathrm{Pb}-\mathrm{Pb}(\mathrm{Zr})$} & \\
\hline & \multicolumn{2}{|c|}{ Itabirito Granitoids $^{(2)} / 2555 \pm 24 \mathrm{Ma} / \mathrm{Pb}-\mathrm{Pb}(\mathrm{Zr})$} & \\
\hline & \multicolumn{2}{|c|}{ Serra da Moeda Pegmatite ${ }^{(2)} / 2608 \pm 24 \mathrm{Ma} / \mathrm{Pb}-\mathrm{Pb}(\mathrm{Zr})$} & \\
\hline
\end{tabular}


TABLE I (continuation)

\begin{tabular}{|c|c|c|}
\hline Event & Igneous activity/age/method & $\begin{array}{l}\text { Stratigraphic unit/ } \\
\text { ages/method }\end{array}$ \\
\hline \multirow[t]{9}{*}{ Transamazônico I ${ }^{(2)}$} & Alto Maranhão Tonalite ${ }^{(4)} / 2130 \pm 2 \mathrm{Ma} / \mathrm{U}-\mathrm{Pb}(\mathrm{Zr})$ & \multirow{9}{*}{$\begin{array}{l}\text { Piracicaba Group } \\
\text { (Cercadinho Formation) } \\
\text { /3353 - 2775 } \mathrm{Ma}^{(16)} \\
\text { /Pb-Pb/Det. } \mathrm{Zr} \\
\text { Caraça Group } \\
\text { (Moeda Formation) } \\
\text { /3294 - 2606Ma }{ }^{(16)} \\
\text { /Pb-Pb/Det. } \mathrm{Zr} \\
\text { Tamanduá Group } \\
\text { (Cambotas Formation) } \\
\text { /2967 - 2258Ma } \\
\text { /Pb-Pb/Det. } \mathrm{Zr}\end{array}$} \\
\hline & $\begin{array}{l}\text { Porto dos Mendes Granitoid }{ }^{(8)} / 2178 \pm 85 \mathrm{Ma} / \mathrm{Rb}-\mathrm{Sr}(\mathrm{RT}) \\
{ }^{(13)} / 2200 \pm 175 \mathrm{Ma} / \mathrm{Rb}-\mathrm{Sr}(\mathrm{RT})\end{array}$ & \\
\hline & $\begin{array}{l}\text { Tabuões Granitoids }^{(9)} / 2232 \pm 75 \mathrm{Ma} / \mathrm{Rb}-\mathrm{Sr}(\mathrm{Rt}) \\
{ }^{(11)} / 2248 \pm 75 \mathrm{M} / \mathrm{Rb}-\mathrm{Sr}(\mathrm{Rt})^{(7)} / 1932 \pm 20 \mathrm{Ma} / \mathrm{Rb}-\mathrm{Sr}(\mathrm{RT})\end{array}$ & \\
\hline & Ritápolis Granitoid $^{(10)} / 2121 \pm 7 \mathrm{Ma} / \mathrm{Pb}-\mathrm{Pb}(\mathrm{Zr})$ & \\
\hline & Serrinha Granitoid ${ }^{(10)} / 2219 \pm 2 \mathrm{Ma} / \mathrm{Pb}-\mathrm{Pb}(\mathrm{Zr})$ & \\
\hline & $2192 \pm 4 \mathrm{Ma} / \mathrm{Pb}-\mathrm{Pb}(\mathrm{Zr})$ & \\
\hline & Cassiterita Granitoid $^{(10)} / 2162 \pm 10 \mathrm{Ma} / \mathrm{Pb}-\mathrm{Pb}(\mathrm{Zr})$ & \\
\hline & Brumado Diorite $^{(10)} / 2131 \pm 4 \mathrm{Ma} / \mathrm{Pb}-\mathrm{Pb}(\mathrm{Zr})$ & \\
\hline & $\begin{array}{l}\text { São Sebastião da Vitória Gabbro } \\
{ }^{(10)} / 2220 \pm / 3 \mathrm{Ma} / \mathrm{Pb}-\mathrm{Pb}(\mathrm{Zr})\end{array}$ & \\
\hline \multirow[t]{3}{*}{ Transamazônico II ${ }^{(2)}$} & Ribeirão Pinheirinho Granitoids ${ }^{(12)} / 2058 \pm 10 \mathrm{Ma} / \mathrm{Pb}-\mathrm{Pb}(\mathrm{Zr})$ & \multirow{3}{*}{$\begin{array}{l}\text { Sabará Group } \\
\text { /3265-2122Ma } \\
\text { /(16) } \\
\text { Itacolomi Group } \\
\text { /3120-2059Ma }{ }^{(16)} \\
\text { /Pb-Pb/Det. } \mathrm{Zr}\end{array}$} \\
\hline & Piranga Syenite $^{(12)} / 2036 \pm 4 \mathrm{Ma} / \mathrm{Pb}-\mathrm{Pb}(\mathrm{Zr})$ & \\
\hline & $\begin{array}{l}\text { São Tiago Granitoids }{ }^{(17)} / 1937 \pm 22 \mathrm{Ma} / \mathrm{U}-\mathrm{Pb}(\mathrm{Zr}) \\
1901 \pm 53 \mathrm{Ma} / \mathrm{U}-\mathrm{Pb}(\mathrm{Zr})\end{array}$ & \\
\hline$?$ & Source-rock of detrital zircon ${ }^{(15)}$ & $\begin{array}{l}\text { Andrelândia Group } \\
/ 1872 \pm 11 \mathrm{Ma}^{(15)} \\
/ \mathrm{U}-\mathrm{Pb} / \text { Det. } \mathrm{Zr}\end{array}$ \\
\hline$?$ & $\begin{array}{l}\text { Guanhães Alkalic Granitoid }{ }^{(14)} / 1729 \pm 14 \mathrm{Ma}^{(14)} / \mathrm{Pb}-\mathrm{Pb}(\mathrm{Zr}) \\
\text { Diamantina K-Metavolcanic }^{(14)} / 1700 \mathrm{Ma}^{(14)} / \mathrm{Pb}-\mathrm{Pb}(\mathrm{Zr})\end{array}$ & \\
\hline Brasiliano & & $\begin{array}{l}\text { Andrelândia Group } \\
/ 604 \pm 16 \mathrm{Ma}^{(15)} \\
/ \mathrm{U}-\mathrm{Pb} / \text { Det. } \mathrm{Zr} \\
\text { Andrelândia Group } \\
/ 567 \pm 11 \mathrm{Ma}^{(15)} \\
/ \mathrm{U}-\mathrm{Pb} / \text { Det. } \mathrm{Zr}\end{array}$ \\
\hline
\end{tabular}

Minerals typical of greenschist facies (chlorite, sericite) also occur. In summary, these rocks firstly experienced granulite-facies metamorphism (plagioclase + quartz + hypersthene \pm diopside \pm orthoclase) followed by amphibolite-facies metamorphic overprinting (microcline \pm plagioclase + quartz \pm hornblende + biotite \pm epidote) contemporaneous with the migmatization/granite genesis, and finally, greenschist facies metamorphism (microcline + quartz + biotite \pm sericite \pm chloritea). In some lithotypes, especially the felsic finer-grained mobilizates, abundant garnet appears, with biotite and opaque minerals. The $\mathrm{cm}$ - to $\mathrm{m}$-thick mafic layers also contain some garnet, biotite, and orthopyroxene. These portions are continuous for tens of meters within the more felsic rock, or are interrupted 


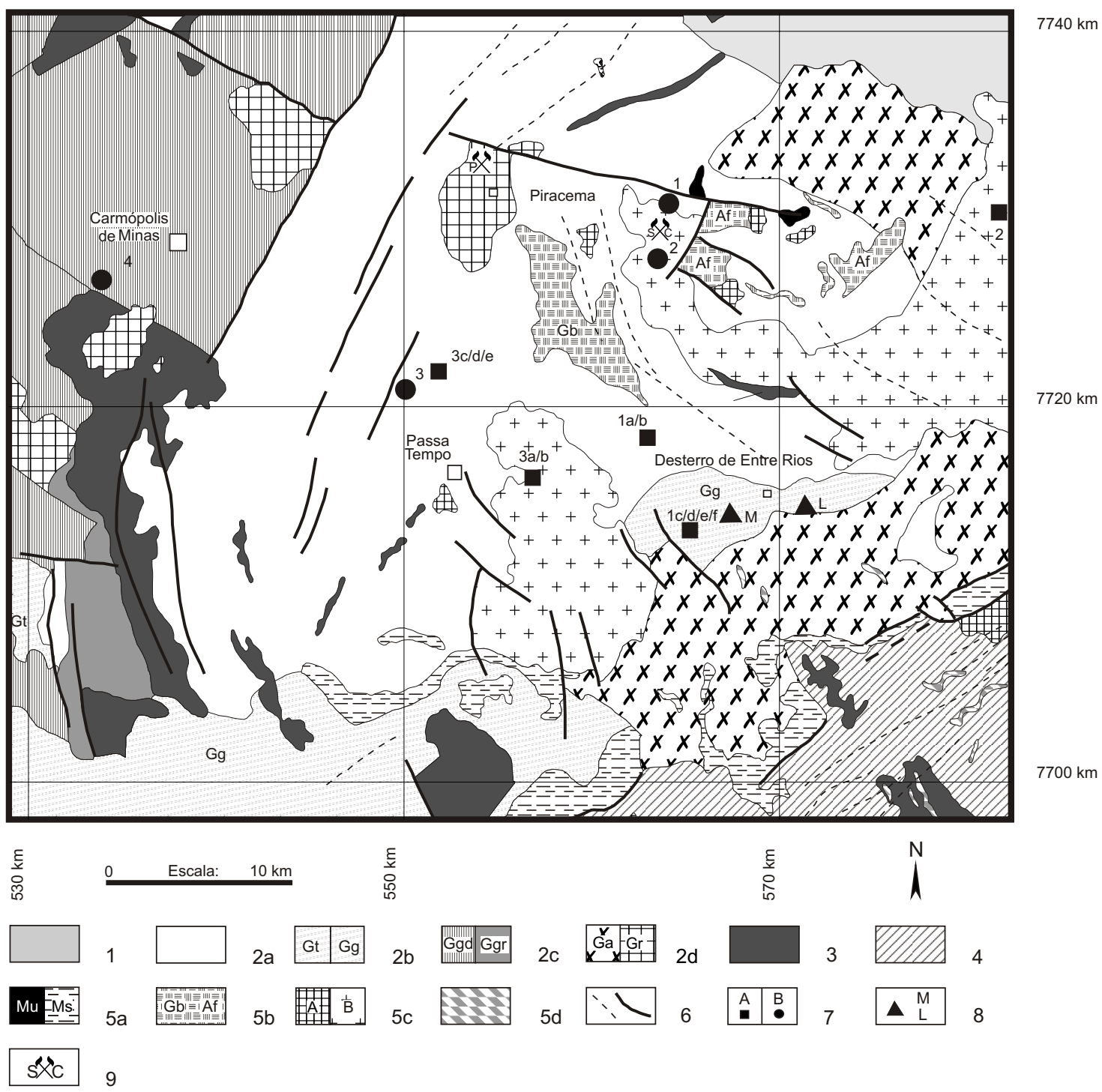

Fig. 2 - Detailed geologic map of the Passa Tempo region (modified after Perillo 2000). Key: 1 - Bonfim Metamorphic Complex; 2 - Passa Tempo Metamorphic Complex [2a - tonalitic-trondhjemitic to granitic gneisses of the granulite facies, $2 \mathrm{~b}-\mathrm{tonalitic}(\mathrm{Gt})$ and granitic (Gg) orthogneisses, 2c-migmatized orthogneisses with granodioritic (Ggd) or granitic (Ggr) mesosome, 2d-anatectic granites (Ga) and rosy granites (Gr)]; 3 - Rio das Velhas Supergroup; 4 - Paleoproterozoic Granites; 5 - Lithodemic units of uncertain age [5a meta-ultrabasic $(\mathrm{Mu})$ and metasedimentary $(\mathrm{Ms})$ rocks: quartzites, ferruginous quartzites, itabirites, quartz-muscovite schists, altered purple schists, $5 \mathrm{~b}$ - gabbros (Gb) and amphibolites (Af), $5 \mathrm{c}$ - somewhat deformed, light-gray granodiorites (A) and variably-deformed, porphyroid, light-gray granites (B), 5d - pegmatites]; 6 - Shear Zones, dashed where less prominent; 7 - Sampled points dated by $\mathrm{Rb}-\mathrm{Sr}$ (A) and K-Ar (B) geochronologic methods (Fiumari et al. 1985, Teixeira 1985); 8 - Location of the samples dated in this work ( $\mathrm{M}=$ mesosome, $\mathrm{L}=$ leucosome); 9 - Quarry location ( $\mathrm{P}=$ Piracema; $\mathrm{SC}=$ Serra dos Caetanos).

by boudinage. The quarry at the Serra dos Caetanos, northeast of Passa Tempo village (Figure 2), exhibits such mobilizates well. In many cases, as in Piracema quarry (Figure 2), the mesosomes are not abundant within felsic masses, and do not preserve pre-migmatization structures. Mesosomes at 


\section{TABLE II}

Geochronologic data of the Passa Tempo Metamorphic Complex and respective interpretations [Teixeira 1985 (*) and

Fiumari et al. 1985], with location indicated in Figure 2.

\begin{tabular}{c|l|c|c|l}
\hline \multicolumn{1}{c|}{ Location } & Sample & Method & Age & Interpretation \\
\hline $1 a / 1 b / 1 c / 1 d / 1 e / f$ & Gneiss (Whole Rock) & $\mathrm{Rb}-\mathrm{Sr}\left({ }^{\mathrm{is}}\right)$ & $2566 \pm 53 \mathrm{Ma}(\mathrm{IR}=0,706)$ & $\begin{array}{l}\text { Retrograde metamorphism } \\
\text { from granulite facies }\end{array}$ \\
\hline 2 & Granite (Whole Rock) & $\mathrm{Rb}-\mathrm{Sr}\left({ }^{\mathrm{is}}\right)$ & $1900 \pm 108 \mathrm{Ma}(\mathrm{IR}=0,709)$ & Crystallization \\
\hline $3 a / 3 b / 3 c / 3 d / 3 e$ & Gneiss (Whole Rock) & $\mathrm{Rb}-\mathrm{Sr}\left({ }^{(\mathrm{is}}\right)\left(^{*}\right)$ & $2280 \pm 220 \mathrm{Ma}(\mathrm{IR}=0,744)$ & $\begin{array}{l}\text { Reworking (isotopic } \\
\text { rehomogenization) }\end{array}$ \\
\hline 1 & Enderbite (Biotite) & $\mathrm{K}-\mathrm{Ar}$ & $1780 \pm 54 \mathrm{Ma}$ & Cooling \\
\hline 2 & Amphibolite (Amphibole) & $\mathrm{K}-\mathrm{Ar}$ & $2005 \pm 60 \mathrm{Ma}$ & Cooling \\
\hline 3 & Gneiss (Biotite) & $\mathrm{K}-\mathrm{Ar}$ & $1745 \pm 52 \mathrm{Ma}$ & Cooling \\
\hline 4 & Gneiss (Biotite) & $\mathrm{K}-\mathrm{Ar}$ & $1845 \pm 55 \mathrm{Ma}$ & Cooling \\
\hline
\end{tabular}

is $=$ isochron

Desterro de Entre Rios village (Figure 2), which we have sampled and dated are quartz-monzonitic and present hornblende, orthopyroxene, opaque minerals, titanite, and zircon. Minerals in the dated quartz-syenitic leucosome include biotite, hornblende, opaque minerals, apatite, epidote, and zircon.

\section{U-Pb GEOCHRONOLOGY}

We extracted zircons from two Passa Tempo Metamorphic Complex lithotypes near the city of Desterro de Entre Rios (Figure 2). A quartz-monzonitic mesosome (OPU 1349) contains orthopyroxene, which guarantees that the rock crystallized in the granulite facies. A quartz-syenitic leucosome (OPU 1348) formed by migmatization that followed highgrade metamorphism event. Initial separation of zircon by standard procedures at the Laboratory of Sample Preparation for Geochronology (LOPAG) of the Department of Geology of the School of Mines of Ouro Preto Federal University was followed by sample chemistry and mass spectrometry, also by standard procedures at the Laboratory of $\mathrm{U}-\mathrm{Pb} \mathrm{Geo}$ chronology of the Center of Geochronologic Research - CPGeo - of the Institute of Geosciences of São Paulo University. The least magnetic zircon fractions were chosen for mechanical abrasion. Transparent, euhedral, colorless zircon crystals (concentrates M3-E, M3-C, M4-D and M2-A), and a light brown (concentrate M3-B) from the mesosome (OPU 1349; Table III) exhibit prisms with axes ratios of the order of $2 / 1$ to $2.5 / 1.5$.

Leucosome zircons (OPU-1348; Table III) are similarly euhedral, transparent, and colorless (concentrate M3-A) to light brown (concentrates M3B, M4-AA and M3-C), a little fractured, with short prisms exhibiting axis ratios varying between 2.5/ 1.5 and 2.0/1.5. Zircons were mechanically abraded with pyrite for 15 minutes in a steel capsule, leached with hot $\mathrm{HNO}_{3}$, rinsed with water, and sonified. From sample OPU-1349, we selected abraded zircon fraction M3, and populations M3-AA(1) and M3-AA(3) for isotopic dilution analysis by standard procedures, employing a mixed ${ }^{205} \mathrm{~Pb}^{235} \mathrm{U}$ spike (Krogh 1973 with minor modification by Basei et al. 1995), and performing calculations using the ISOPLOT program (Ludwig 1998). From sample OPU-1348, we chose population M4-AA for analysis. CPGeo uses a VG 354 thermal ionization mass spectrometer with 5-cup collectors and a Daly detector.

\section{DISCUSSION OF U-Pb DATA}

Data from the seven zircon populations of sample OPU 1349 (Table III) define a discordia line that intercept Concordia at $2622 \pm 18 \mathrm{Ma}$ (Figure 6), and for sample OPU-1348 (Table III), discordiaConcordia intercept is at $2599 \pm 45 \mathrm{Ma}$ (Figure 6). 
(A)
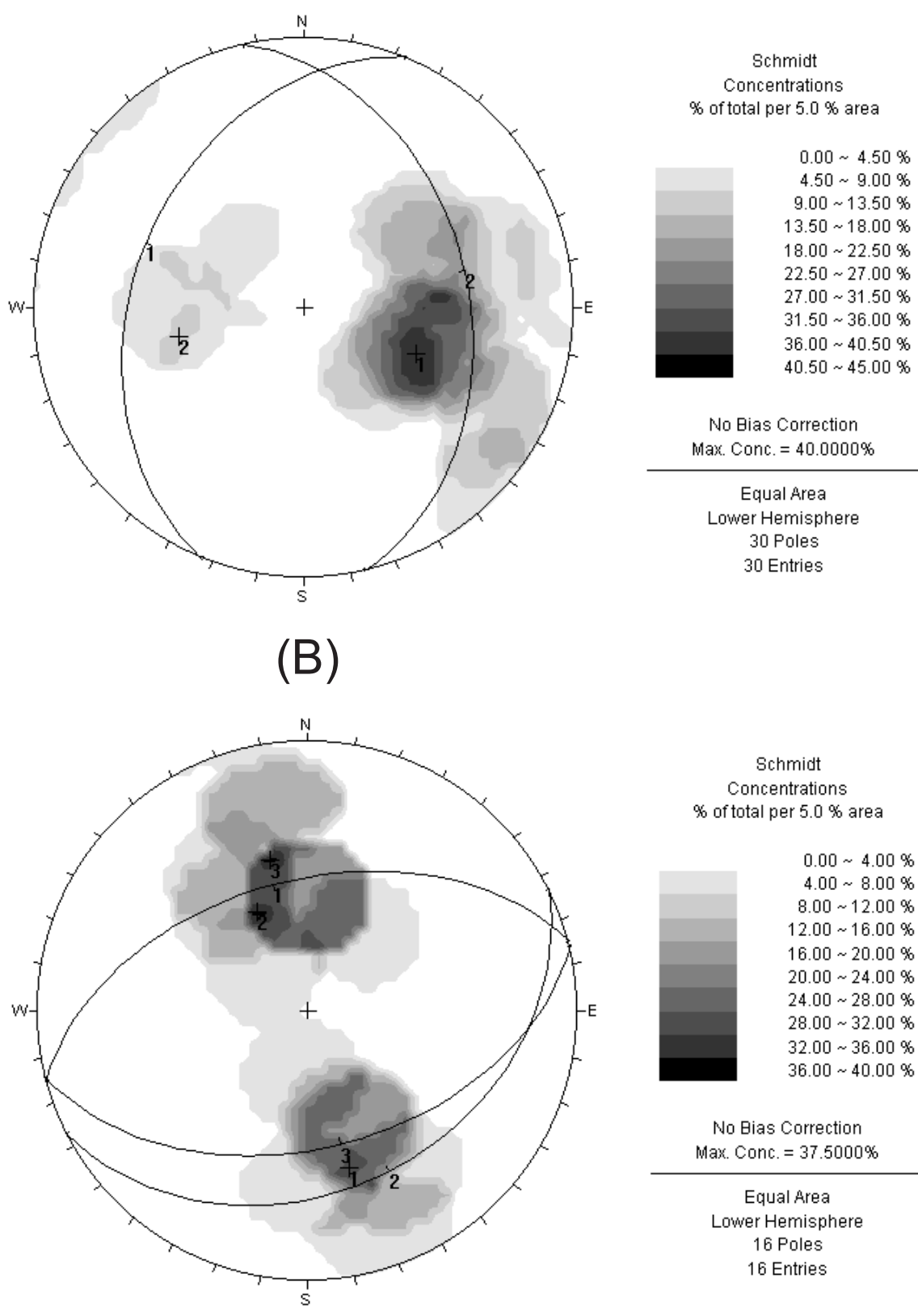

No Bias Correction Max. Conc. $=40.0000 \%$

Equal Area Lower Hemisphere 30 Poles 30 Entries

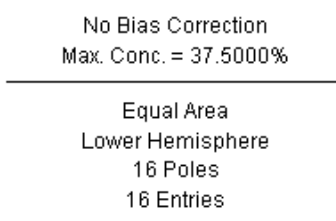

Fig. 3 - Stereograms showing poles of the gneissic banding (a), shearing planes (b), with respective maximum concentration planes.

In both data sets the analytical points diverge from Concordia and, as discussed by Krogh and Davis (1975), this results mainly from ubiquitous although not severe fractures in zircon crystals. Populations of abraded zircons yield analytical points that are closer to Concordia (Figure 6). 


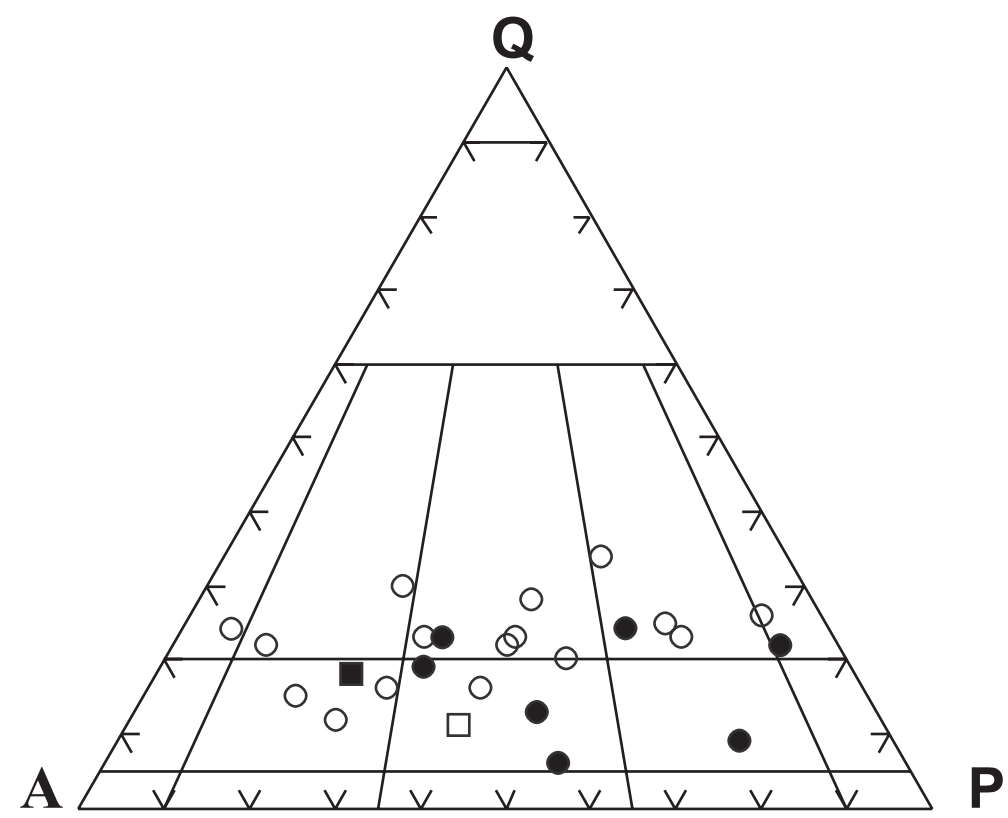

Fig. 4 - QAP modal diagram (Streckeisen 1976) for gneissic rocks, granitoids, granitic leucosomes and Passa Tempo Metamorphic Complex felsic mobilizates (gneisses: open circles; felsic mobilizates: filled circles; dated mesosome: open square; dated leucosome: filled square).

Dodson (1973) developed the theory of a mineral isotope closure during cooling, which occurs at least $800^{\circ} \mathrm{C}$ for the U-Pb system in zircon (Heaman and Parrish 1991). The presence of orthopyroxene in the mesosome (sample OPU-1349) and elsewhere in Passa Tempo Metamorphic Complex indicates that regional metamorphism had reached granulite facies that, according petrographic evidence, formed under anhydrous conditions. We interpreted the $2622 \pm 18 \mathrm{Ma} \mathrm{U}-\mathrm{Pb}$ age as a minimum for the granulite-facies metamorphism, reflecting the peak regional metamorphism. In one of the analyzed fractions, zircon crystals with slightly rounded pyramidal faces contain small, apparently oriented globular fluid inclusions. Pupin (1976) states that such zircons typically have crystallized at high pressure, in eclogite or granulite facies host rock. The alkaligranitic leucosome (OPU 1348), containing microcline, plagioclase, quartz, biotite, mesoperthite, and hornblende, besides secondary epidote, opaque minerals and zircon, represents regional migmatization proper. The presence of amphiboles and micro- cline (the latter probably from potassic feldspar) that clearly formed at the expense of orthopyroxene demonstrates that felsic products were generated from later melting in the presence of aqueous fluids at shallower crustal levels. Some leucosome zircons (not analyzed) display conspicuous overgrowths. Pupin (1976) noted that aqueous fluids play an important role in making zircon overgrowths at middle lithosphere level.

As observed by Ashworth (1985), reactions related to the formation of "minimum granites" in laboratory experiments have always had potassic feldspar as one of the final products. In one of these reactions, biotite + garnet + albite + quartz, yielding potassic feldspar + garnet + orthopyroxene $+\mathrm{H}_{2} \mathrm{O}$, at increasing temperature and pressure conditions, abundant formation of potassic feldspar can occur. The replacement of potassic feldspar by myrmekite (plagioclase + quartz), muscovite, and quartz, common in many migmatites, are interpreted as retrograde metamorphic reactions (Ashworth 1985).

Retrograde metamorphic features such as re- 

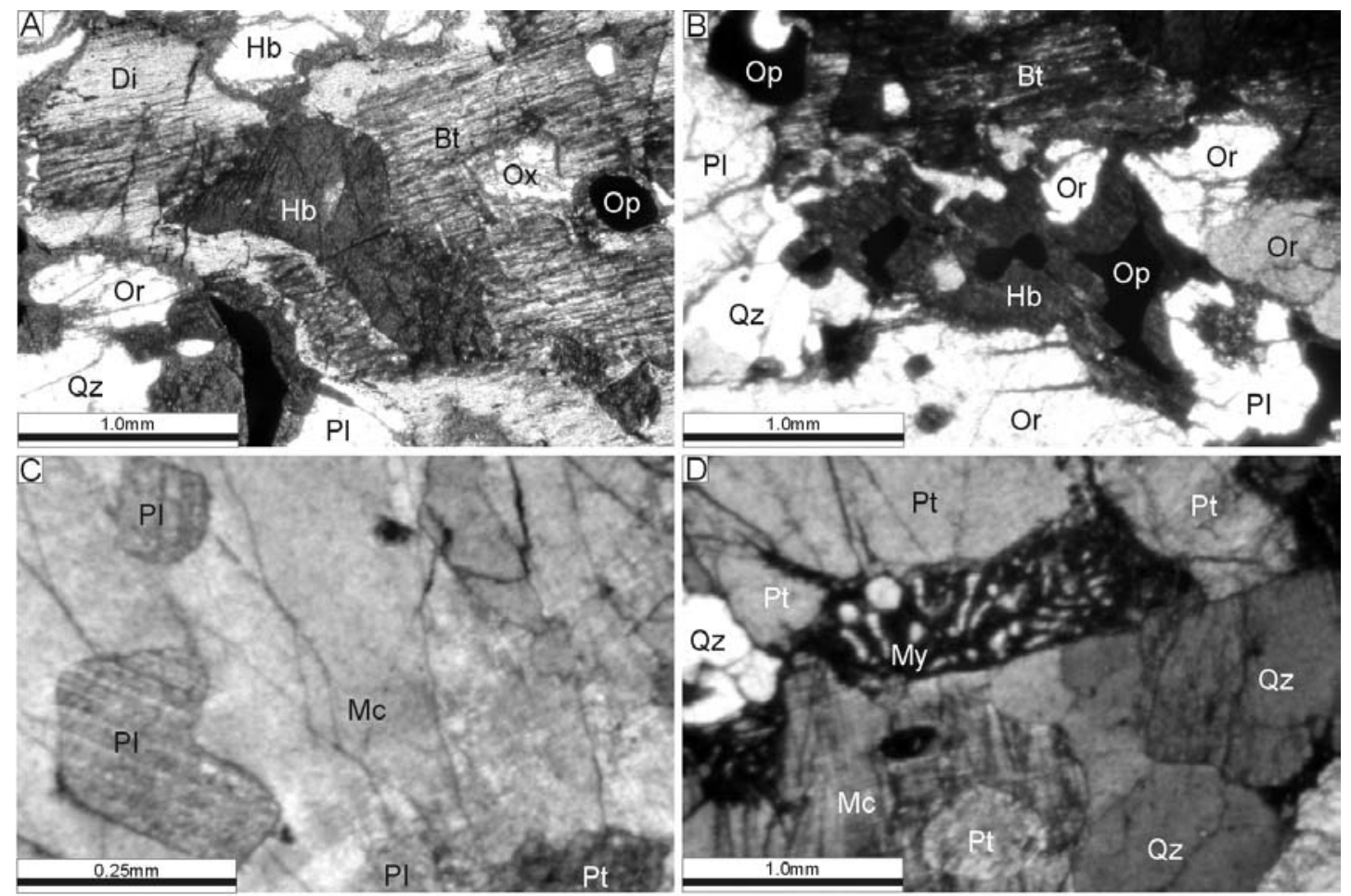

Fig. 5 - Photomicrographs, plane light (a, b) and polarized light (c, d) illustrating microtextural features of the mesosome (a, b, c), leucosome (c, d). Key: Qz = quartz, $\mathrm{Pt}=$ perthite, $\mathrm{Bt}=$ biotite, $\mathrm{Op}=$ opaque, $\mathrm{Pl}=$ plagioclase, $\mathrm{My}=$ myrmekite, $\mathrm{Hb}=$ hornblende, Or $=$ orthoclase, $\mathrm{Ox}=$ orthopyroxene, $\mathrm{Di}=$ diopside (The scale is indicated in each photomicrograph).
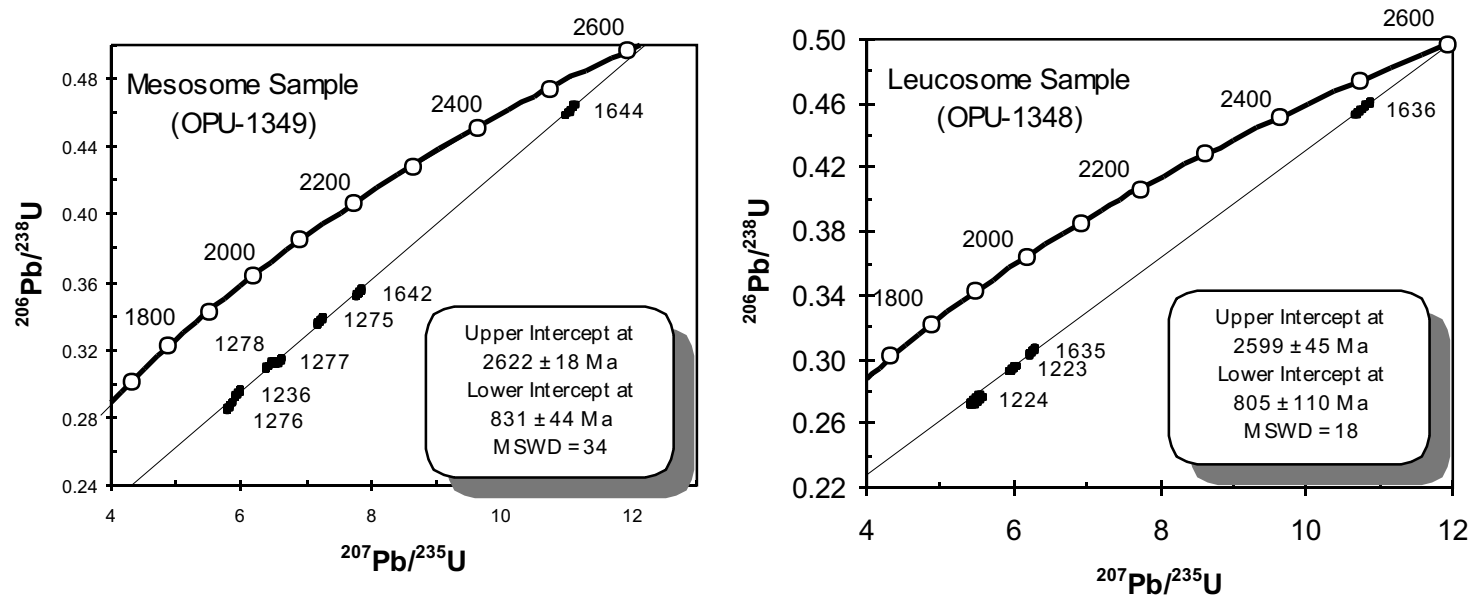

Fig. 6 - U-Pb Concordia diagrams for mesosome zircons (OPU 1349) and leucosome zircons (OPU 1348).

placement of pyroxene by hornblende and biotite, presence of myrmekite at the contact between plagioclase and potassic feldspar, and exsolution lamellae of orthopyroxene in clinopyroxene, to- gether relict texture and paragenesis, are observed in several Passa Tempo Metamorphic Complex samples. Thus it is likely that a quick crustal uplift led to the crystallization of microcline in the meso- 
TABLE III

Isotopic data obtained from selected zircon fractions of mesosome (OPU 1349) and leucosome (OPU 1348) samples.

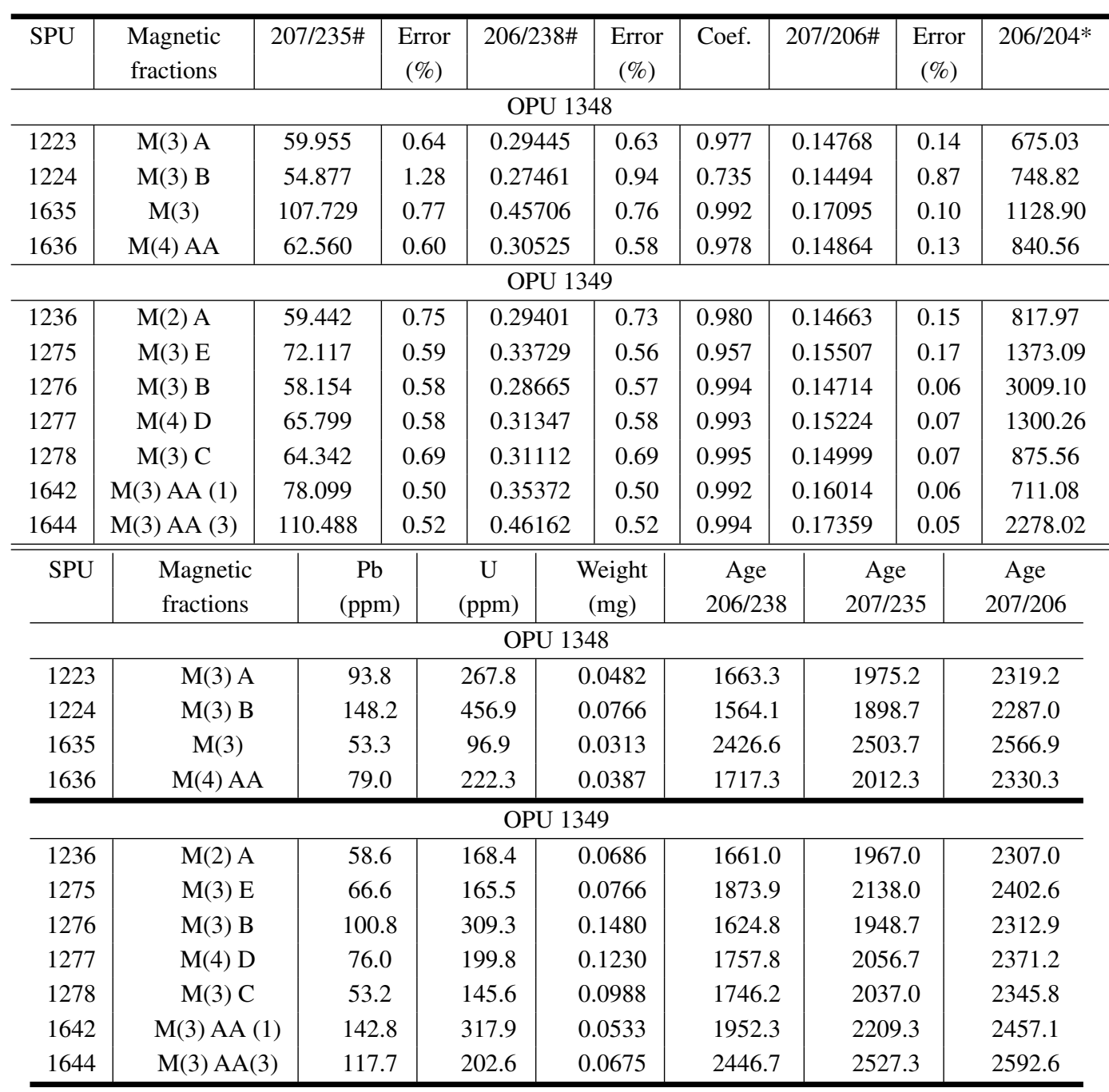

SPU: laboratory number; magnetic fractions: numbers in parentheses indicated the tilt used on FRANTZ separator at $1.5 \mathrm{~A}$ current; \# $\mathrm{Pb}$ radiogenic corrected for blank and initial $\mathrm{Pb}$; $\mathrm{U}$ corrected for blank; $*$ not corrected for blank or non-radiogenic $\mathrm{Pb}$; total $\mathrm{U}$ and $\mathrm{Pb}$ concentrations corrected for analytical blank; ages given in Ma using Ludwig Isoplot/Ex program (1998), decay constants recommended by Steiger and Jäger (1977).

some during the migmatization processes, and preserved anhydrous minerals from being totally replaced. In our study, the ages obtained from mesosome $(2622 \pm 18 \mathrm{Ma})$ and leucosome $(2599 \pm$ $45 \mathrm{Ma})$ are the same within error, suggesting that termination of granulite facies metamorphism and subsequent migmatization occurred in prompt succession.

\section{CONCLUDING REMARKS}

The U-Pb Concordia upper-intercept age of granulite-facies metamorphism of the studied Passa Tempo Metamorphic Complex is ca. $2622 \pm$ $18 \mathrm{Ma}$. It precedes, or occurred early within the 2612-2550 Ma interval of granitic genesis recorded in various places Southern São Francisco Craton 
metamorphic complexes. The Passa Tempo Metamorphic Complex leucosome age, $2599 \pm 45 \mathrm{Ma}$, is virtually the same within error. Passa Tempo Metamorphic Complex granite associated with leucosome could have been the source rock that supplied 2606 Ma detrital zircons to metasediments of lower unit of Minas Supergroup (Machado et al. 1996). Then, granulite-facies metamorphism and migmatization/granite genesis must have preceded deposition of this lower unit of the Minas Supergroup.

Our new U-Pb data support the hypothesis of a Neoarchean RV3E between 2.61 and $2.55 \mathrm{Ga}$ (Endo 1997), under a ductile-brittle, dextral transpressional regime, with a N-S flow plane and tectonic transport from NE toward the SW. This event must have closed a large Neoarchean orogenic cycle, where the magmatism, metamorphism and deformation processes are well recorded in the São Francisco Craton and throughout South America (Almeida 1981). In this case, the tectonic environment for the RV3E would imply a continent-continent collision and is temporally in agreement with the continental superagglutination model proposed by Yale and Carpenter (1998), which states that a large continental mass, also envisaged by Condie (1998), formed between 2850 and 2500 Ma. Such agglutination would correspond to countless continental collisions related to the Jequié cycle. In this model, the duration of these supercontinents would be marked by the episodic occurrence of large juvenile igneous provinces and large mafic dike suites, products of mantle plumes formed due to buffering of the mantle under large continental masses, modifying its convective activity.

Lagarde et al. (1992), classify the emplacement of granitoids in collisional orogens in three stages: 1 - syn-crustal thickening (granites with crustal petrographic and geochemical signatures); 2 - post-crustal thickening (granites with very different geochemical and petrographic signatures as a function of the variable involvement of crustal and mantle material coming from active magmatic sources); 3 - late-orogenic (calc-alkaline to potassic calc-alkaline granites). The Passa Tempo Meta- morphic Complex geologic data here presented, especially those related to the compositional characteristics of the granitoids, seem to indicate that the reworking in question must have occurred in a latetectonic stage.

\section{ACKNOWLEDGMENTS}

The authors thank the Research Financing Agency of Minas Gerais State (FAPEMIG) for financial support for Research Projects CRA 2697/98 and CRA $225 / 02$. This work was made possible thanks to $L a$ boratório de Preparação de Amostras para Geocronologia and Laboratório de Laminação do Departamento de Geologia da Universidade Federal de Ouro Preto and Laboratório de Geocronologia U$\mathrm{Pb}$ do Instituto de Geociências da Universidade de São Paulo personnel/technicians and equipment. The authors also thank the referees for their helpful suggestions.

\section{RESUMO}

O Complexo Metamórfico Passa Tempo é um dos diversos complexos metamórficos que constituem a crosta siálica arqueana da porção meridional do Cráton São Francisco. Ele engloba rochas gnáissicas portadoras de hiperstênio, com corpos máfico-ultramáficos orientados NW ou EW subordinados e granitóides granodioríticos a sienograníti$\cos$, fracamente foliados e de coloração clara. Corpos de granitóides isolados de dimensões decamétricas a quilométricas são o produto de generalizada migmatização que seguiu metamorfismo de facies granulito. Para determinar as idades do metamorfismo de fácies granulito e da gênese dos granitos, nós obtivemos idades $\mathrm{U}-\mathrm{Pb}$ em zircões extraídos de mesossoma e leucossoma de gnaisses migmatíticos. Para o mesossoma, a discórdia que intercepta a Concórdia em $2622 \pm 18$ Ma é interpretada como idade mínima para o metamorfismo de fácies granulito. Para o leucossoma, o intercepto superior da discórdia em $2599 \pm 45$ Ma corresponde a migmatização e à gênese dos granitos. Metamorfismo e magmatismo contemporâneos têm sido documentados em outras partes do Cráton São Francisco, especialmente em sua porção sul, demonstrando extenso e vigoroso retrabalhamento da crosta siálica ao fim do Neoarqueano. 
Palavras-chave: cráton, Arqueano, complexo metamórfico, geocronologia U-Pb, evolução tectônica, Brasil.

\section{REFERENCES}

Alkmim FF, Brito Neves BB and Alves JAC. 1993. Arcabouço tectônico do Cráton São Francisco - Uma revisão. In: Simpósio SOBRE o CRÁton do SÃo Francisco, 1., Salvador. Anais..., Salvador. 1993, p. 39-41.

Almeida FFM. 1977. O Cráton São Francisco. Rev Bras Geo 7: 349-364.

Almeida FFM. 1981. O Cráton do Paramirim e sua relação com o do São Francisco. In: Simpósıo DO Cráton SÃo Francisco E SUAS FaIXAS MARgINAIS. Salvador. Anais..., Salvador, p. 1-10.

Almeida FFM, Hasui Y, Brito Neves BB and Fuck RA. 1981. Brazilian structural provinces: an introduction. Earth Sci Reviews 17: 1-29.

Ashworth JR. 1985. Introduction. In: Ashworth JR (Ed.), Migmatites, Glasgow: Blackie and Son Limited, p. 1-35.

Ávila CA. 2000. Geologia, Petrografia e Geocronologia de Corpos Plutônicos Paleoproterozóicos da Borda Meridional do Cráton São Francisco, Região de São João del Rei, Minas Gerais. Unpublished PhD Thesis, IG, Federal University of Rio de Janeiro, 401p.

Basei MAS, Siga Júnior O, Sato K and Sproesser WM. 1995. A Metodologia Urânio- Chumbo na Universidade de São Paulo. Princípios Metodológicos, Aplicações e Resultados Obtidos. An Acad Bras Cienc 67: 221-237.

Brandalise LA. 1991. Texto Explicativo. In: Projeto Levantamentos Geológicos Básicos do Brasil, Folha SF.23-X-C-III Barbacena, 162p.

Carneiro MA. 1992. O Complexo Metamórfico Bonfim Setentrional (Quadrilátero Ferrífero, Minas Gerais): Litoestratigrafia e Evolução Geológica de um Segmento de Crosta Continental do Arqueano. Unpublished PhD Thesis, IG/USP, University of São Paulo, 233 p.

Carneiro MA, Teixeira W, Carvalho Júnior IM and Fernandes RA. 1998. Ensialic Tectonic Setting of the Archean Rio das Velhas Greenstone Belt: Nd and $\mathrm{Pb}$ isotopic evidence from the Bonfim Metamorphic complex, Quadrilátero ferrífero, Brazil. Rev Bras Geo 28: 189-200.
CondIE KC. 1998. Episodic continental growth and supercontinents: a mantle avalanche connection? Earth and Planetary Sci Letters 163: 97-108.

Correia da Costa PCC. 1999. Episódio de Formação de Crosta Continental Arqueana no Cráton São Francisco Meridional: um exemplo a partir da Região de Candeias-Campo Belo, MG. Unpublished MSc. Thesis, DEGEO/EM, Federal University of Ouro Preto, 132p.

Delhal J and Demaiffe D. 1985. U-Pb Archean geochronology of the São Francisco craton (Eastern Brazil). Rev Bras Geo 15: 55-60.

Dodson MH. 1973. Closure temperature in cooling geochronological and petrological systems. Cont to Min Pet 40: 259-274.

DORR II JVN. 1969. Physiographic, stratigraphic and structural development of the Quadrilátero Ferrífero, Minas Gerais, Brazil. Washington, U.S. Geological Survey (Professional Paper 641A), p. 110.

Dussin IA, Dussin TM, Charvet J, Cocherie A AND Rossi P. 1993. Single zircon dating by stepwise $\mathrm{Pb}$ evaporation of Middle Proterozoic magmatism in the Espinhaço range, SE São Francisco Craton (Minas Gerais, Brazil). In: Simpósio SOBRE o CRÁton do SÃo Francisco, 2., Salvador. Anais..., Salvador, p. $39-42$.

ENDo I. 1997. Regimes tectônicos do Arqueano e Proterozóico no interior da Placa Sanfranciscana: Quadrilátero Ferrífero e suas adjacências, Minas Gerais. Unpublished PhD Thesis, IG/USP, University of São Paulo, 243p.

Fernandes RA. 2000. Etapas de formação de crosta continental (do Mesarqueano ao Mesoproterzóico) no Cráton São Francisco Meridional. Unpublished MSc. Thesis, DEGEO/EM, Federal University of Ouro Preto, $128 \mathrm{p}$.

Fiumari SL, Padilha AV and AraúJo MC. 1985. Complexo Granulítico de Passa Tempo. In: Simpósio dE Geologia de Minas Gerais, 03., Belo Horizonte. Anais..., Belo Horizonte, 1985, p. 60-67.

Grossi SAD JH, Pinto GP ANd Duarte CL. 1983. Geologia do Distrito Manganesífero de Conselheiro Lafaiete, MG. In: Simpósio de Geologia de Minas Gerais, 2., Belo Horizonte. Anais..., Belo Horizonte, p. $259-270$.

Heaman L and Parrish R. 1991. U-Pb geochronology of accessory minerals. In: HEAMAN L AND LUDDEN 
JN (Ed.), Short course handbook on applications on isotope systems to problems in geology. Toronto: Mineralogical Association of Canada, p. 59-102.

Jordt-Evangelista H, Peres GG, Macambira MJG. 2000. $\mathrm{Pb}-\mathrm{Pb}$ zircon dating of Paleoproterozoic calcalkaline/alkaline magmatism in the Southeastern São Francisco Craton region, Brazil. Rev Bras Geo 30: 174-176.

KROGH TE. 1973. A low contamination method for decomposition of zircon and extraction of $\mathrm{U}$ and $\mathrm{Pb}$ for isotopic age determination. Geoch Cosm Acta 37: 485-494.

Krogh TE and Davis GL. 1975. Alteration in zircons and differential dissolution of altered and metamict zircon. Washington: Carnegie Institute Yearbook, 74, p. 619-623.

Lagarde JL, Capdevila R and Fourcade S. 1992. Granites et collision continentale: l'exemple des garnitoïdes carboniféres dans la chine hercynienne ouest-européene. Bul Soc Géo France 163: 597-610.

Lima JOA, Ferreira CM, Schmidt JC, D'Elboux CV, Moreira MD and Oliveira Júnior OA. 1974. Mapa Geológico-Setor G da Geotransversal E-W. In: ConvênIo EFMOP/DNPM, Folhas SE.23ZD-IV,V,VI e SF.23-XB-I,II,III.

LUDWIG KR. 1998. ISOPLOT. A Plotting and Regression Program for Radiogenic-Isotope Data.

Machado Filho L, Ribeiro MW, Gonzales SR, Schenini CA, Santos Neto A, Palmeira RCB, Pires JL, Teixeira W and Castro HEF. 1983. Geologia. In: Projeto RADAMBRASIL, Folhas SF.23/24 32: 31-129.

Machado N and CaRneiro MA. 1992. U-Pb evidence of late Archean tectono-thermal activity in the southern São Francisco shield, Brazil. Can J Earth Sci 29: 2341-2346.

Machado N, Noce CM, Ladeira EA and Belo de Oliveira O. 1992. U-Pb geochronology of Archean magmatism and Proterozoic metamorphism in the Quadrilátero Ferrífero, southern São Francisco craton, Brazil. Geo Soc America Bul 104: 1221-1227.

Machado N, Schrank A, Noce CM and Gauthier G. 1996. Ages of detrital zircon from ArcheanPaleoproterozoic sequences: implications for Greenstone Belt setting and evolution of Transamazonian foreland basin in Quadrilátero Ferrífero, southeast Brazil. Earth and Planetary Sci Letters 141: 259-276.
Mennert KR. 1968. Migmatites and the Origin of Granitic Rocks, 2nd ed., Amsterdam: Elsevier Publishing Company. 405p.

Noce CM. 1995. Geocronologia dos eventos Magmáticos, sedimentares e metamórficos na região do Quadrilátero Ferrífero, Minas Gerais. Unpublished PhD Thesis, IG/USP, University of São Paulo, 128p.

Noce CM, Teixeira W, Quéméneur JJG and Martins VTS. 1997. Isotopic data on the Paleoproterozoic Mineiro belt, southern São Francisco Craton: a review. In: South American Symposium on Isotope Geology - Brazil. Campos do Jordão. Extended Abstracts..., Campos do Jordão, p. 213-215.

Noce CM, Machado N and Teixeira W. 1998. U$\mathrm{Pb}$ Geochronology of gneisses and granitoids in the Quadrilátero Ferrífero (Southern São Francisco Craton): ages constrains for Archean and Paleoproterozoic magmatism and metamorphism. Rev Bras Geo 28: 95-102.

Oliveira AH and Carneiro MA. 2001. Campo Belo Metamorphic Complex: Evolution of an Archean sialic crust of the southern São Francisco Craton in Minas Gerais (Brazil). An Acad Bras Cienc 73: 397-415.

Paciullo FVP, Ribeiro A, Andreis RR and Trouw RAJ. 2000. The Andrelândia basin, a Neoproterozoic intraplate continental margin, Southern Brasília Belt, Brazil. Rev Bras Geo 30: 200-202.

Perillo JA. 2000. Mapa Geológico. In: Programa Levantamentos Geológicos Básicos do Brasil, Folha SF. 23-X-A Divinópolis.

Pinese JPP, Teixeira W, Quéméneur JJG, Piccirillo EM, Petrini R and Bellieni G. 1997. Geochemistry and isotope geology of the basic-noritic dykes in the southern part of the São Francisco craton. In: South American Symposium on Isotope GeolOGY - BraZIL. Campos do Jordão. Extended Abstracts..., Campos do Jordão, p. 240-241.

PuPIN JP. 1976. Signification des Caractères Morphologiques du Zircon Commun des Roches en Petrologie. Base de la Methode Typologique. Applicattions. France. 394p. (Thèse de Doctorat Es-Sciences, Université de Nice, France).

QuÉmÉnEUR JJG. 1987. Esboço estratigráfico, estrutural e metamórfico da Serra de Bom Sucesso, MG. In: Simpósio de Geologia de Minas Gerais, 04., Belo Horizonte. Anais..., Belo Horizonte, 1987, p. 135-148. 
QuÉmÉneur JJG AND Noce CM. 2000. Geochemistry and petrology of felsic and mafic suites related to the Paleoproterozoic Transamazonian Orogeny in Minas Gerais, Brazil. Rev Bras Geo 30: 87-90.

QuémÉneur JJG and VidAL P. 1989. Primeiras datações radiométricas dos granitos da região de São João del Rei (Minas Gerais). In: Simpósio de Geologia dE Minas Gerais, 5., Belo Horizonte. Anais..., Belo Horizonte, 1989, p. 50-54.

Raposo FO. 1991. Texto Explicativo. In: Projeto Levantamentos Geológicos Básicos do Brasil, Folha SF.23-X-B-IV Rio Espera, 174p.

Romano AW, Bertrand JM, Michard A ANd ZimmerMANN JL. 1991. Tectonique tangencielle et décrochements d'âge Protérozoïque inférieur (orogènese transamazonienne, environ $2000 \mathrm{Ma}$ ) au Nord du "Quadrilatère ferrifère"' (Minas Gerais, Brésil): Compt Rend Acad Sci Paris 313: 1195-1200.

Schorscher HD, Santana FC, Polonia JC and MoREIRA JPM. 1982. Quadrilátero Ferrífero-Minas Gerais State: Rio das Velhas greenstone belt and Proterozoic rocks: In: InTERNATIONAL SyMPOSIUM Archean and Early Proterozoic Geology EvoLution and Metalllogenesis (ISAP). Salvador. Excursions Annex..., Salvador, 44p.

Silva SL. 1985. Texto Explicativo. In: Projeto Mapas Metalogenéticos e de Previsão de Recursos Minerais, Folha SE.23-Z-C Belo Horizonte, 17p.

Söllner F AND Trow RAJ. 1997. The Andrelândia Depositional Cycle (Minas Gerais/Brazil), a Post Transamazonic Sequence South of the São Francisco Craton: Evidence from U-Pb Dating on Zircons of a Metassediment. J South American Earth Sci 10: 21-28.
STEIGER RH AND JäGER E. 1977. Subcommission on geochronology: convention on the use of decay constants in Geo and Cosmochronology. Earth Planet Sci Lett 36: 359-362.

Streckeisen A. 1976. To each plutonic rock its proper name. Earth Sci Reviews 12: 1-33.

Teixeira W. 1985. A Evolução Geotectônica da Porção Meridional do Cráton do São Francisco, com base em Interpretações Geocronológicas. Unpublished $\mathrm{PhD}$ Thesis, IG/USP, University of São Paulo, 207p.

Teixeira W and Martins VT. 1996. Granitos Paleoproterozóicos da Porção Meridional do Cráton São Francisco: Estudos isotópicos de $\mathrm{Sr}$ e Nd. In: Relatório de Projeto de Pesquisa. São Paulo: USP/ FAPESP, 28p.

Teixeira W, Cordani UG, Kawashita K, Taylor PN AND VAN Schmus WR. 1987. Archean and Early Proterozoic crustal evolution in the southern part of the São Francisco craton. In: International Symposium on Granite and Associated MineralizaTIONS, 1., Salvador. Extended Abstracts..., Salvador, p. 37-40.

Teixeira W, Cordani UG, Nutman AP and Sato K. 1998. Polyphase Archean evolution in the Campo Belo metamorphic complex, Southern São Francisco Craton, Brazil. SHRIMP U-Pb zircon evidence. J South American Earth Sci 11: 279-289.

Valeriano CM, Teixeira W, Heilbron M and Simões LSA. 2000. Southern Brasília Belt (SE Brazil): Tectonic discontinuities, K-Ar data and evolution during the Neoproterozoic Brasiliano Orogeny. Rev Bras Geo 30: 195-199.

Yale LB And Carpenter SJ. 1998. Large igneous provinces and giant dike swarms: proxies for supercontinent cyclicity and mantle convection. Earth and Planet Sci Letters, 163: 109-122. 